\title{
Chitinilyticum aquatile gen. nov., sp. nov., a chitinolytic bacterium isolated from a freshwater pond used for Pacific white shrimp culture
}

\author{
Correspondence \\ Shu-Chen Chang \\ doris@ccsun.tajen.edu.tw
}

\author{
Shu-Chen Chang, ${ }^{1,2}$ Wen-Ming Chen, ${ }^{3}$ Jih-Terng Wang ${ }^{4}$ \\ and Ming-Chang $\mathrm{Wu}^{2}$
}

\author{
${ }^{1}$ Department of Food Science and Technology, Tajen University, 20 Weishin Rd, YanPu Shiang, \\ Pingtung City 907, Taiwan, ROC \\ ${ }^{2}$ Department of Food Science, National Pingtung University of Science and Technology, \\ Pingtung, Taiwan, ROC \\ ${ }^{3}$ Department of Seafood Science, National Kaohsiung Marine University, Kaohsiung, Taiwan, ROC \\ ${ }^{4}$ Department of Biotechnology, Tajen University, Pingtung, Taiwan, ROC
}

\begin{abstract}
Strain $\mathrm{c} 14^{\top}$, originally isolated from surface water of a freshwater pond located in Pingtung (southern Taiwan) used for culture of Pacific white shrimp (Litopenaeus vannamei), was subjected to a polyphasic taxonomic approach. The strain exhibited strong chitinolytic activity and was able to grow under aerobic and anaerobic conditions by utilizing chitin exclusively as the carbon, nitrogen and energy source. Phylogenetic analysis of the 16S rRNA gene sequence revealed a clear affiliation of the proposed bacterium to the Betaproteobacteria, most closely related to Chitinibacter tainanensis $\mathrm{S} 1^{\top}$, Deefgea rivuli $\mathrm{WB} 3.4-79^{\top}$ and Silvimonas terrae $\mathrm{KM}-45^{\top}$, with 94.6, 93.6 and $92.9 \% 16 \mathrm{~S}$ rRNA gene sequence similarity, respectively. The predominant fatty acids detected in cells of strain $c 14^{\top}$ were $C_{16: 0}, C_{18: 1} \omega 7 c$ and summed feature $3\left(C_{16: 1} \omega 7 c\right.$ and/or $\mathrm{C}_{15: 0}$ iso 2-OH). The $\mathrm{G}+\mathrm{C}$ content of the genomic DNA was $69.5( \pm 1.0) \mathrm{mol} \%$.

Biochemical, physiological, chemotaxonomic and phylogenetic analyses showed that strain $\mathrm{c} 14^{\top}$ could not be assigned to any known genus of the Betaproteobacteria. Therefore, strain $c 14^{\top}$ is classified within a novel genus and species, for which the name Chitinilyticum aquatile gen. nov., sp. nov. is proposed. The type strain of Chitinilyticum aquatile is c14 ${ }^{\top}$ (=LMG $23346^{\top}$ $=$ BCRC $17533^{\top}$ ).
\end{abstract}

Chitin is a common constituent of crustacean shells, cell walls of fungi, certain green algae and exoskeletons of insects and is the second most abundant polysaccharide in nature (after cellulose). It is an insoluble homopolymer composed of linear chains of $\beta$-1,4-linked $N$-acetyl- $\beta$-Dglucosamine (GlcNAc) residues, which are highly crosslinked by hydrogen bonds. Chitin and its partially deacetylated derivatives exhibit interesting properties and constitute a valuable raw material for biomedical, agricultural and cosmetic applications (Shigemasa \& Minami, 1996). Annually, enormous amounts of chitin are synthesized in the biosphere, as much as $10^{10}$ to $10^{11}$ metric tons (Gooday, 1990), but only a tiny minority remains in the

Abbreviations: GlcNAc, $N$-acetyl- $\beta$-D-glucosamine; $\mathrm{PHB}$, poly- $\beta$-hydroxybutyrate.

The GenBank/EMBL/DDBJ accession number for the 16S rRNA gene sequence of strain $c 14^{\top}$ is DQ3 14581 .

An HPLC profile of chitin degradation products of strain $c 14^{\top}$ is available as supplementary material with the online version of this paper. environment. The high turnover rate of the polysaccharide is attributed primarily to micro-organisms that degrade chitin, allowing carbon and nitrogen to return to the ecosystem (Gooday, 1990). It seems likely that shrimp culturing ponds could be a rich source of chitin-degrading bacteria. Since shrimp farming has contributed significantly to the economy of southern Taiwan, there are many types of shrimp ponds scattered around the Pingtung region. Some of them are very close to the coast, but some are far away from the sea, and that results in various water salinities in the ponds. Thus, the diverse culture types provide a variety of drastically different ecosystems in which micro-organisms can develop.

In our previous study, a strain of chitin-degrading bacteria, Chitinimonas taiwanensis $\mathrm{cf}^{\mathrm{T}}$, was isolated from a freshwater pond for shrimp (freshwater giant prawn, Macrobrachium rosenbergii) culture (Chang et al., 2004). In this study, a water sample was collected from a freshwater pond for Pacific white shrimp (Litopenaeus vannamei) culture located in the Pingtung countryside in 
southern Taiwan. The temperature of the pond water was about $25{ }^{\circ} \mathrm{C}$ and the $\mathrm{pH}$ was approximately 7 . The selected medium for isolation of chitin-degrading bacterium was enriched with $100 \mathrm{ml}$ sample water with $0.5 \%$ (w/v) autoclaved colloidal chitin. The initial culture was incubated at $25{ }^{\circ} \mathrm{C}$ with agitation at 125 r.p.m. Colloidal chitin was prepared from commercial chitin (Ohka Chemical) as described by Chang et al. (2004). After 5 days of incubation, the enrichment broth was diluted with sterile distilled water and spread onto chitin basal (CB) medium (Chang et al., 2004). A bacterial strain that showed large clear zones around the colonies resulting from chitin degradation was isolated and designated $\mathrm{c} 14^{\mathrm{T}}$. The colony morphology of strain $\mathrm{c} 14^{\mathrm{T}}$ was clearly different compared with that of Chitinimonas taiwanensis $\mathrm{cf}^{\mathrm{T}}$ (Chang et al., 2004). Consequently, the organism was subjected to a polyphasic taxonomic study that demonstrated its status as a member of a novel genus and species.

Bacterial cells were observed by phase-contrast microscopy (Leica DM 2000) in the lag, exponential and stationary phases of growth to ascertain their morphology. The motility of cells was examined by the hanging drop method. Flagellum staining was performed using the Spot Test flagella stain (BD Difco). Gram staining was performed using the Gram stain set S (BD Difco) and the Ryu non-staining KOH method (Powers, 1995). Poly$\beta$-hydroxybutyrate (PHB) granule accumulation was observed by light microscopy after Sudan black staining. For scanning electron microscopy observations, specimens were fixed in $25 \%$ glutaraldehyde in phosphate buffer (pH 7) for $20 \mathrm{~min}$ and then washed with phosphate buffer. Secondary fixation was done with $4 \%$ osmium tetroxide in phosphate buffer for $40 \mathrm{~min}$, again followed by a buffer rinse. After the secondary fix, dehydration was accomplished through a series of ethanol solutions $(50,70,80,90$, 95 and $100 \%$ ); each change was held for $10 \mathrm{~min}$. The specimens were then critical-point dried (Hitachi HCP-2), sputter-coated with gold (Hitachi E-1010) and examined with a digital scanning electron microscope (Hitachi S3500N).

The $\mathrm{pH}$ range for growth was determined by measuring optical densities (wavelength $595 \mathrm{~nm}$ ) of the culture grown in tryptic soy broth (TSB; BD Difco). The $\mathrm{pH}$ of the medium was adjusted to $\mathrm{pH} 3-11$ at intervals of $1.0 \mathrm{pH}$ unit by using appropriate biological buffers: glycine $/ \mathrm{HCl}$, citrate $/ \mathrm{Na}_{2} \mathrm{HPO}_{4}$, phosphate buffer and glycine $/ \mathrm{NaOH}$ were used for $\mathrm{pH}$ values below 4, 4.0-8.0, 6.0-8.0 and 9.0-11.0, respectively. For the determination of the temperature range for growth, cells were incubated in $\mathrm{CB}$ broth at temperatures between 4 and $50{ }^{\circ} \mathrm{C}\left(4{ }^{\circ} \mathrm{C}\right.$ and 10 to $50{ }^{\circ} \mathrm{C}$ at intervals of $5{ }^{\circ} \mathrm{C}$ ) using an orbital water-bath shaker (125 r.p.m.). Tolerance of $\mathrm{NaCl}$ was determined by adjusting the salinity of $\mathrm{CB}$ medium to values between 0 and $3.0 \% \mathrm{NaCl}(\mathrm{w} / \mathrm{v})(0,0.25,0.3,0.5,0.75,1,2$ and $3 \%)$. Anaerobic cultivation was performed on $\mathrm{CB}$ and $\mathrm{R} 2 \mathrm{~A}$ media in the Oxoid AnaeroGen system. Culture supernatant of strain $\mathrm{c} 14^{\mathrm{T}}$ was used to detect chitinolytic production by HPLC and by the hydrolysis of fluorogenic substrate analogues [(GlcNAC $)_{n}$, where $n=1-6$; Sigma] as described previously (Chang et al., 2004).

Light microscope investigations revealed that cells of strain $\mathrm{c} 14^{\mathrm{T}}$ were Gram-negative, rod-shaped, $0.3-0.4 \mu \mathrm{m}$ wide and 2.5-4.0 $\mu \mathrm{m}$ long, and contained PHB granules. Cells were motile by means of single polar flagella. A scanning electron micrograph of strain $c 14^{\mathrm{T}}$ is shown in Fig. 1.

Strain $\mathrm{c} 14^{\mathrm{T}}$ formed visible colonies (approx. $1.0-1.5 \mathrm{~mm}$ in diameter) on CB agar after 3 days of incubation at $35^{\circ} \mathrm{C}$. Colonies were cream-white in colour, circular and convex with entire edges. Surrounding the colonies, a colourless clear zone was observed that extended to more than double the colony diameter, indicating that chitinolysis was performed by strain $\mathrm{c} 14^{\mathrm{T}}$ during growth. With a medium containing only minerals and chitin, strain $c 14^{\mathrm{T}}$ still exhibited a reasonable growth rate under both aerobic and anaerobic conditions, indicating that the organism could use chitin as a sole carbon, nitrogen and energy source for growth. In addition, vitamins and yeast extract were not needed as supplements for growth in mineral medium. Strain $\mathrm{c} 14^{\mathrm{T}}$ could also be grown on nutrient and tryptic soy media. Strain $\mathrm{c} 14^{\mathrm{T}}$ grew at temperatures ranging from 15 to $40{ }^{\circ} \mathrm{C}, \mathrm{pH}$ values between 7 and 11 and $\mathrm{NaCl}$ concentrations between 0 and $0.75 \%$. Optimal growth conditions were 30 $35{ }^{\circ} \mathrm{C}, \mathrm{pH} 8$ and $0.25 \% \mathrm{NaCl}$. When the chitinolytic products were examined by HPLC and hydrolysis of fluorogenic substrates, the main product that remained in the $\mathrm{c} 14^{\mathrm{T}}$ culture medium was a disaccharide [chitodiose; $(\mathrm{GlcNAc})_{2}$ ], as shown in Supplementary Fig. S1, available in IJSEM Online. Clearly, strain $\mathrm{c} 14^{\mathrm{T}}$ could be distinguished from Chitinimonas taiwanensis $\mathrm{cf}^{\mathrm{T}}$, which produced chitotriose $\left[(\mathrm{GlcNAc})_{3}\right]$ (Chang et al., 2004), and Chitinibacter tainanensis $\mathrm{S1}^{\mathrm{T}}$, which produced GlcNAc monosaccharides (Chern et al., 2004), as the major products of chitin cleavage.

Extraction of genomic DNA and PCR amplification and sequencing of the 16S rRNA gene were carried out as

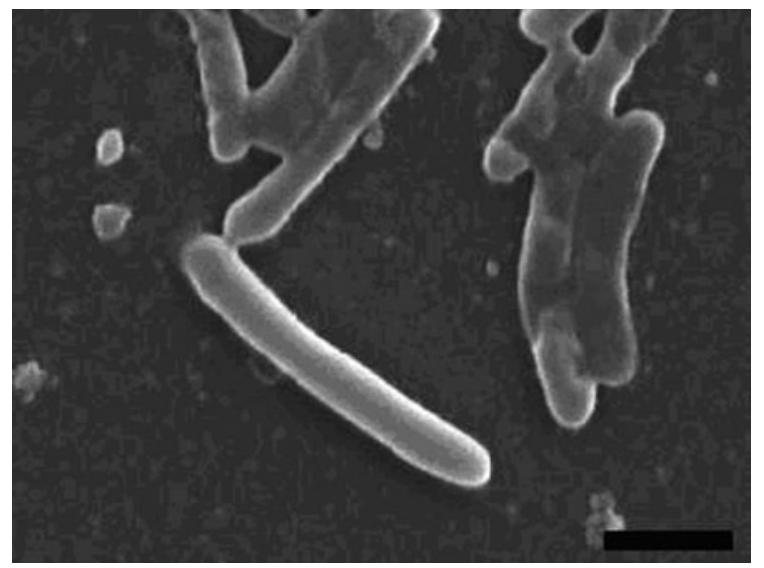

Fig. 1. Electron micrograph of cells of strain $\mathrm{c} 14^{\top}$. Bar, $1 \mu \mathrm{m}$. 
described previously (Chen et al., 2001). Sequence reaction fragments were separated using a DNA sequencer (ABI PRISM 310 instrument; Applied Biosystems) and sequence assembly was done by using the Fragment Assembly System program from the Wisconsin Package 9.1 (Genetics Computer Group, 1995). The nearly complete $16 \mathrm{~S}$ rRNA gene sequence of strain $\mathrm{c} 14^{\mathrm{T}}$ was compared with corresponding sequences taken from the GenBank and Ribosomal Database Project II databases. Multiplesequence alignment including strain $\mathrm{c} 14^{\mathrm{T}}$ and its closest relatives was achieved using the BioEdit program (Hall, 1999) and MEGA version 3.1 (Kumar et al., 2004). Phylogenetic reconstruction was inferred by using the maximum-likelihood (Felsenstein, 1981), maximum-parsimony (Kluge \& Farris, 1969) and neighbour-joining (Saitou \& Nei, 1987) tree-making algorithms. An evolutionary distance matrix was generated for the neighbourjoining algorithm using the distance model of Jukes \& Cantor (1969) and bootstrap analysis (1000 resamplings).

A nearly complete $16 \mathrm{~S}$ rRNA gene sequence (1455 nt) of strain $\mathrm{c} 14^{\mathrm{T}}$ was obtained and revealed that strain $\mathrm{c} 14^{\mathrm{T}}$ belonged to the Betaproteobacteria. A phylogenetic tree inferred on the basis of evolutionary distances by using the neighbour-joining method (Fig. 2) indicated that strain $\mathrm{c} 14^{\mathrm{T}}$ formed a distinct lineage within the family Neisseriaceae. Sequence similarity calculations using pairwise alignment obtained from the EzTaxon database (Chun et al., 2007) showed the greatest degree of similarity to Chitinibacter tainanensis $\mathrm{S1}^{\mathrm{T}}$ (94.6\% similarity) (Chern et al., 2004), Deefgea rivuli $\mathrm{WB} \quad 3.4-79^{\mathrm{T}}(93.3 \%)$
(Stackebrandt et al., 2007), Silvimonas terrae KM- $45^{\mathrm{T}}$ (92.9\%) (Yang et al., 2005), Formivibrio citricus DSM $6150^{\mathrm{T}}(92.4 \%)$ (Hippe et al., 1999), Iodobacter fluviatilis ATCC $33051^{\mathrm{T}}(92.2 \%)$ (Logan, 1989) and Chitinimonas taiwanensis $\mathrm{cf}^{\mathrm{T}}(92.0 \%)$ (Chang et al., 2004). The sequence similarity with other species belonging to the Betaproteobacteria was less than $92 \%$. The overall topologies of the phylogenetic trees obtained with the neighbour-joining, maximum-likelihood and maximum-parsimony methods were similar.

Fluorometric DNA-DNA hybridization experiments were performed with photobiotin-labelled probes as described by Ezaki et al. (1989). Hybridization was conducted in $50 \%$ formamide at $50{ }^{\circ} \mathrm{C}$. Each experiment was done in triplicate and the data are displayed as means of triplicate experiments. Strain $\mathrm{c} 14^{\mathrm{T}}$ showed relatively low DNA-DNA hybridization with its closest phylogenetic neighbour, Chitinibacter tainanensis BCRC $17254^{\mathrm{T}}(21 \pm 3 \%)$.

A DNA sample was prepared and degraded enzymically into nucleosides as described by Mesbah et al. (1989). The nucleoside mixture obtained was then separated by reversed-phase HPLC equipped with a Cosmosil 5C18 column (Waters). Non-methylated lambda phage DNA (Sigma) was used as the calibration reference. Each experiment was conducted in triplicate and the data are displayed as the mean of triplicate experiments. The $\mathrm{G}+\mathrm{C}$ content of strain $\mathrm{c} 14^{\mathrm{T}}$ was $69.5( \pm 1.0) \mathrm{mol} \%$.

Cellular fatty acids were analysed in cells grown on TSB agar for 2 days. The cellular fatty acids were saponified and

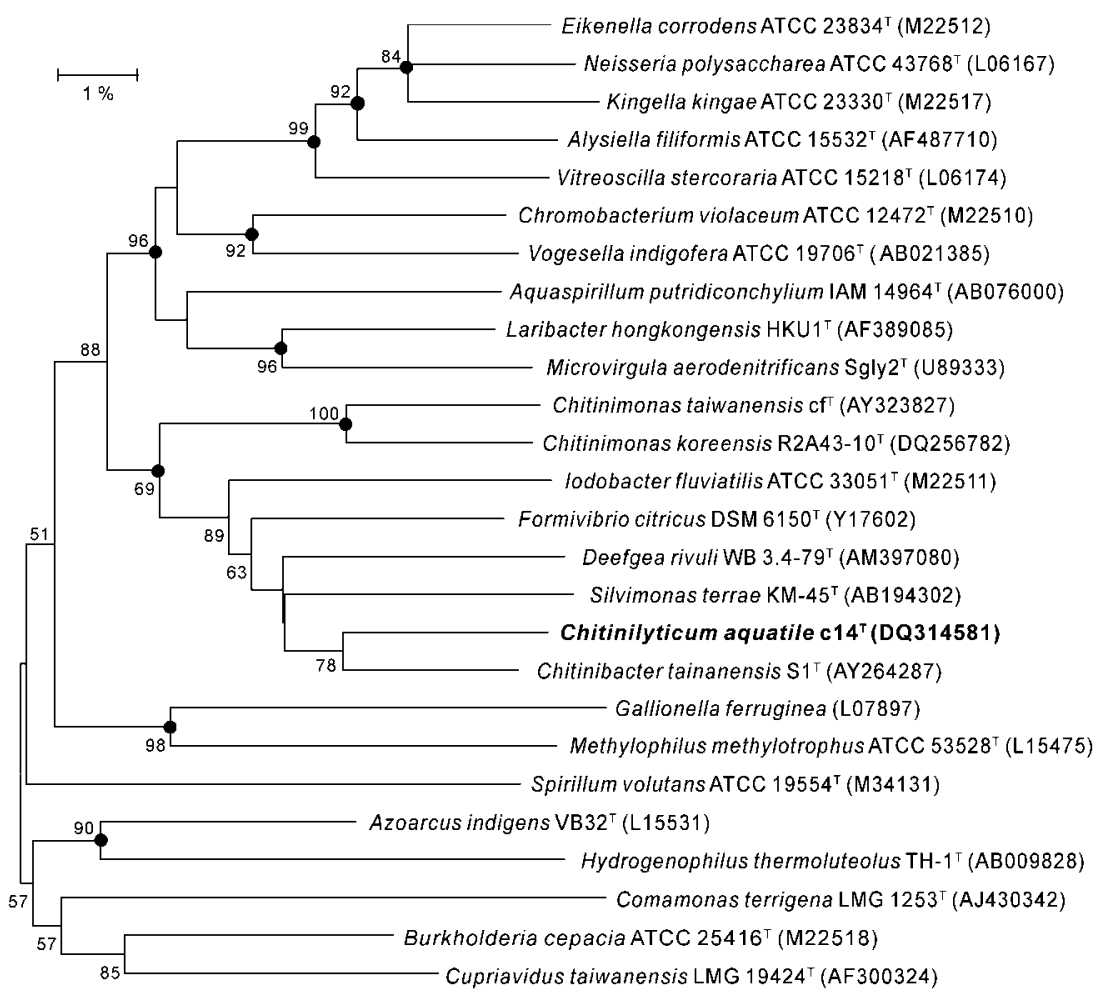

Fig. 2. Neighbour-joining phylogenetic tree of strain $c 14^{\top}$ and its relatives in the Betaproteobacteria based on 16S rRNA gene sequence comparisons. Bar, $1 \%$ sequence dissimilarity (1 substitution per 100 nucleotide positions). Bootstrap values (\%) are indicated at branches from 1000 resamplings; only values $>50 \%$ are shown. GenBank accession numbers are shown in parentheses. Filled circles indicate generic branches recovered by using maximum-parsimony. 
methylated and then extracted according to the standard protocol of the Microbial Identification System (Sasser, 1990; MIDI Inc., 1999). The fatty acids analysed by GC (Hewlett Packard 6890) were identified by the Microbial Identification software package. The major cellular fatty acids of strain $c 14^{\mathrm{T}}$ were $\mathrm{C}_{16: 0}, \mathrm{C}_{18: 1} \omega 7 c$ and summed feature $3\left(\mathrm{C}_{16: 1} \omega 7 c\right.$ and/or $\mathrm{C}_{15: 0}$ iso2-OH $)$. The detailed fatty acid compositions of strain $\mathrm{c} 14^{\mathrm{T}}$ and its close phylogenetic neighbours are shown in Table 1 . The fatty acid profile of strain $\mathrm{c}^{1} 4^{\mathrm{T}}$ was similar to those of Chitinibacter tainanensis $\mathrm{S}^{\mathrm{T}}$, S. terrae $\mathrm{KM}-45^{\mathrm{T}}$, D. rivuli WB $3.4-79^{\mathrm{T}}$ and F. citricus DSM $6150^{\mathrm{T}}$, which all contained predominantly $\mathrm{C}_{16: 0}, \mathrm{C}_{18: 1} \omega 7 c$ and summed feature 3 , but differed in the proportions of fatty acids (Table 1). The respiratory quinone composition of strain $\mathrm{c} 14^{\mathrm{T}}$ (grown aerobically in $\mathrm{CB}$ broth at $30^{\circ} \mathrm{C}$ ) was analysed using previously described HPLC methods (Collins, 1985, 1994). Ubiquinones Q8 (extracted from Escherichia coli ATCC $11775^{\mathrm{T}}$ ) and Q10 (Sigma) were used as standards.

Table 1. Comparison of fatty acid profiles of strain $c 14^{\top}$ and its phylogenetically closest relatives

Strains: 1, $\mathrm{c} 14^{\mathrm{T}} ; 2$, Chitinibacter tainanensis $\mathrm{S}^{\mathrm{T}}$ (data from Chern et al., 2004); 3, Silvimonas terrae $\mathrm{KM}-45^{\mathrm{T}}$ (Yang et al., 2005); 4, Deefgea rivuli WB $3.4-79^{\mathrm{T}}$ (Stackebrandt et al., 2007); 5, Formivibrio citricus DSM $6150^{\mathrm{T}}$ (Stackebrandt et al., 2007). In order to obtain biomass for fatty acid extraction, strain $\mathrm{c} 14^{\mathrm{T}}$, Chitinibacter tainanensis $\mathrm{S}^{\mathrm{T}}$, S. terrae $\mathrm{KM}-45^{\mathrm{T}}$ and D. rivuli WB $3.4-79^{\mathrm{T}}$ were grown on TSB agar for 2 days at $30^{\circ} \mathrm{C} ; \mathrm{F}$. citricus DSM $6150^{\mathrm{T}}$ was grown anaerobically on medium DSM 505. Values are percentages of total fatty acids; -, not detected/not reported.

\begin{tabular}{|lccccc|}
\hline Fatty acid & $\mathbf{1}$ & $\mathbf{2}$ & $\mathbf{3}$ & $\mathbf{4}$ & $\mathbf{5}$ \\
\hline $\mathrm{C}_{12: 0}$ & 2.8 & 2.6 & 3.6 & 2.7 & 5.3 \\
$\mathrm{C}_{12: 0} 3-\mathrm{OH}$ & 2.6 & 3.9 & - & 2.5 & - \\
$\mathrm{C}_{14: 1} \omega 5 c$ & 0.8 & - & - & - & - \\
$\mathrm{C}_{14: 1}$ & - & - & - & - & 1.2 \\
$\mathrm{C}_{14: 0}$ & 2.5 & 0.5 & 6.4 & 2.0 & 1.6 \\
$\mathrm{C}_{15: 1} \omega 8 c$ & - & 0.3 & - & - & - \\
$\mathrm{C}_{15: 1} \omega 6 c$ & - & 0.3 & - & 1.5 & - \\
$\mathrm{C}_{15: 0}$ & - & 0.8 & - & 2.9 & - \\
$\mathrm{C}_{16: 1} \omega 5 c$ & 0.7 & 0.6 & - & - & - \\
$\mathrm{C}_{16: 0}$ & 23.0 & 16.7 & 33.5 & 20.7 & 11.9 \\
$\mathrm{C}_{16: 0} 3-\mathrm{OH}$ & 0.3 & 1.3 & - & - & - \\
$\mathrm{C}_{17: 0}$ cyclo & - & 0.3 & 15.3 & - & - \\
$\mathrm{C}_{17: 1} \omega 6 c$ & 0.2 & - & - & - & - \\
$\mathrm{C}_{17: 0}$ & - & 0.3 & - & - & - \\
$\mathrm{C}_{18: 1} \omega 7 c$ & 23.3 & 19.9 & 14.7 & 3.4 & 10.8 \\
$\mathrm{C}_{18: 1} \omega 5 c$ & - & 0.2 & - & - & - \\
$\mathrm{C}_{18: 0}$ & 0.1 & 0.8 & - & - & - \\
$11-$ Methyl C $18: 1 \omega 7 c$ & - & 0.1 & - & - & - \\
$10-$ Methyl C $\mathrm{C}_{19: 0}$ & 2.4 & 2.0 & - & - & - \\
Summed feature $3^{*}$ & 41.3 & 48.6 & 21.8 & 60.1 & 57.7 \\
Summed feature $4^{*}$ & - & - & 3.4 & 2.0 & 9.3 \\
& & & & & \\
\hline
\end{tabular}

*Summed feature 3 comprises $\mathrm{C}_{16: 1} \omega 7 c$ and/or $\mathrm{C}_{15: 0}$ iso 2-OH; summed feature 4 comprises $\mathrm{C}_{14: 0} 3-\mathrm{OH}$ and/or $\mathrm{C}_{16: 1}$ iso $\mathrm{I}$.
Ubiquinone 8 (Q8) was the only isoprenoid quinone present in strain $\mathrm{c} 14^{\mathrm{T}}$.

Strain $\mathrm{c} 14^{\mathrm{T}}$ was characterized biochemically by using Biolog GN2 and API 20NE and API ZYM (bioMérieux) microtest systems according to the manufacturers' instructions. Catalase activity was determined by bubble production in a $10 \%(\mathrm{v} / \mathrm{v}) \mathrm{H}_{2} \mathrm{O}_{2}$ solution. Oxidase activity was determined on filter paper moistened with a $1 \%(\mathrm{w} / \mathrm{v})$ aqueous solution of $N, N, N^{\prime}, N^{\prime}$-tetramethyl-p-phenylenediamine. Strain $\mathrm{c} 14^{\mathrm{T}}$ was also examined for a broad range of phenotypic properties using conventional methods (MacFaddin, 2000). Susceptibility to antimicrobial agents was determined by a disc diffusion assay. The cell suspension was diluted to 0.5 McFarland standard in sterile saline after reaching the exponential growth phase and then spread onto $\mathrm{CB}$ medium and incubated at $35^{\circ} \mathrm{C}$. Antimicrobial discs (Difco) used in this experiment separately contained amikacin $(30 \mu \mathrm{g})$, ampicillin $(10 \mu \mathrm{g})$, chloramphenicol $(30 \mu \mathrm{g})$, erythromycin $(15 \mu \mathrm{g})$, gentamicin $(10 \mu \mathrm{g})$, kanamycin $(30 \mu \mathrm{g})$, nalidixic acid $(30 \mu \mathrm{g})$, novobiocin $(30 \mu \mathrm{g})$, rifampicin $(5 \mu \mathrm{g})$, penicillin $\mathrm{G}(10 \mathrm{U})$, streptomycin $(10 \mu \mathrm{g})$ and tetracycline $(30 \mu \mathrm{g})$. The effect of antibiotics on cell growth was assessed after 3 days of incubation at $35{ }^{\circ} \mathrm{C}$ and susceptibility was scored based on the distance from the edge of the clear zone to that of the disc ( $>3 \mathrm{~mm}$, susceptible; $1-3 \mathrm{~mm}$, moderately susceptible; $<1 \mathrm{~mm}$, resistant).

The differences in phenotypic and biochemical characteristics between strain $\mathrm{c} 14^{\mathrm{T}}$ and related phylogenetic neighbours are summarized in Table 2. Strain $\mathrm{c} 14^{\mathrm{T}}$ can be clearly distinguished from Chitinibacter tainanensis $\mathrm{S1}^{\mathrm{T}}$ by the abilities to grow anaerobically, reduce nitrate, ferment glucose, hydrolyse gelatin and assimilate mannose. Differential phenotypic characteristics between strain $\mathrm{c} 14^{\mathrm{T}}$ and $S$. terrae $\mathrm{KM}-45^{\mathrm{T}}$ include that strain $\mathrm{c} 14^{\mathrm{T}}$ can hydrolyse gelatin and lacks activities of $\beta$-galactosidase and $\beta$-glucosidase. Strain $\mathrm{c} 14^{\mathrm{T}}$ can be clearly distinguished from D. rivuli WB $3.4-79^{\mathrm{T}}$ by its abilities to ferment glucose, hydrolyse chitin, grow at $40{ }^{\circ} \mathrm{C}$ and hydrolyse gelatin. While strain $\mathrm{c} 14^{\mathrm{T}}$ is facultatively anaerobic, F. citricus DSM $6150^{\mathrm{T}}$ was described as strictly anaerobic (Tanaka et al., 1991).

It is now generally accepted that bacteria with a $\mathrm{G}+\mathrm{C}$ content difference of more than $10 \mathrm{~mol} \%$ should not be classified within the same genus (Wayne et al., 1987). Also, 16S rRNA sequence similarities between two bacteria of less than $95 \%$ are an indication of affiliation to different genera (Ludwig et al., 1998). Strain $\mathrm{c} 14^{\mathrm{T}}$ most likely represents a species of a new genus, since the $16 \mathrm{~S}$ rRNA gene sequence similarity to its closest relatives with validly published names, Chitinibacter tainanensis $\mathrm{S} 1^{\mathrm{T}}$, S. terrae $\mathrm{KM}-45^{\mathrm{T}}$ and D. rivuli WB $3.4-79^{\mathrm{T}}$, is $94.4,92.7$ and $92.6 \%$, respectively. The $\mathrm{G}+\mathrm{C}$ content of $\mathrm{c} 14^{\mathrm{T}}(69.5 \mathrm{~mol} \%)$ is also significantly higher than those of Chitinibacter tainanensis $\mathrm{Sl}^{\mathrm{T}}$ (56 mol\%), S. terrae $\mathrm{KM}-45^{\mathrm{T}}(58 \mathrm{~mol} \%)$ and D. rivuli WB $3.4-79^{\mathrm{T}}$ (48.5 mol\%). Moreover, strain $\mathrm{c} 14^{\mathrm{T}}$ can be 
Table 2. Difference in phenotypic and biochemical characteristics between strain $c 14^{\top}$ and its phylogenetically closest relatives

Strains: 1 , c14 ${ }^{\mathrm{T}}$; 2, Chitinibacter tainanensis $\mathrm{S}^{\mathrm{T}}$ (data from Chern et al., 2004); 3, S. terrae KM-45 ${ }^{\mathrm{T}}$ (Yang et al., 2005); 4, D. rivuli WB 3.4-79 (Stackebrandt et al., 2007); 5, F. citricus DSM $6150^{\mathrm{T}}$ (Tanaka et al., 1991; Hippe et al., 1999; data for chitin hydrolysis taken from Chern et al., 2004). + , Positive; -, negative; ND, no data available.

\begin{tabular}{|c|c|c|c|c|c|}
\hline Characteristic & 1 & 2 & 3 & 4 & 5 \\
\hline Source & Freshwater & Soil & Soil & Hard-water creek & $\begin{array}{c}\text { Anoxic freshwater } \\
\text { mud }\end{array}$ \\
\hline Morphology & $\begin{array}{c}\text { Rods, straight to } \\
\text { slightly curved }\end{array}$ & $\begin{array}{c}\text { Rods, straight to } \\
\text { slightly curved }\end{array}$ & $\begin{array}{l}\text { Rods, single or in } \\
\text { pairs }\end{array}$ & $\begin{array}{c}\text { Rods, straight to } \\
\text { slightly curved }\end{array}$ & $\begin{array}{c}\text { Curved rods, single } \\
\text { or in pairs }\end{array}$ \\
\hline Relation to $\mathrm{O}_{2}$ & $\begin{array}{c}\text { Facultatively } \\
\text { anaerobic }\end{array}$ & Strictly aerobic & $\begin{array}{c}\text { Facultatively } \\
\text { anaerobic }\end{array}$ & $\begin{array}{c}\text { Facultatively } \\
\text { anaerobic }\end{array}$ & Strictly anaerobic \\
\hline Catalase & + & + & + & + & - \\
\hline Chitin hydrolysis & + & + & + & - & - \\
\hline Growth at $40{ }^{\circ} \mathrm{C}$ & + & + & + & - & - \\
\hline \multicolumn{6}{|l|}{ API 20NE results } \\
\hline Nitrate reduction & + & - & + & + & ND \\
\hline Fermentation of glucose & + & - & + & - & $\mathrm{ND}$ \\
\hline Gelatin hydrolysis & + & - & - & - & $\mathrm{ND}$ \\
\hline$\beta$-Glucosidase & - & - & + & - & ND \\
\hline$\beta$-Galactosidase & - & - & + & - & ND \\
\hline Maltose assimilation & - & - & + & - & ND \\
\hline Mannose assimilation & + & - & + & - & ND \\
\hline $\mathrm{N}$-Acetylglucosamine assimilation & + & + & + & + & $\mathrm{ND}$ \\
\hline Gluconate assimilation & + & + & + & + & $\mathrm{ND}$ \\
\hline DNA G $+C$ content $(\mathrm{mol} \%)$ & 69.5 & 56 & 58 & 48.5 & 61 \\
\hline
\end{tabular}

readily distinguished from its nearest phylogenetic neighbours, Chitinibacter tainanensis $\mathrm{S}^{\mathrm{T}}$, S. terrae $\mathrm{KM}-45^{\mathrm{T}}, D$. rivuli WB $3.4-79^{\mathrm{T}}$ and $F$. citricus DSM $6150^{\mathrm{T}}$, by fatty acid compositions and phenotypic and biochemical characteristics. Therefore, based on phenotypic and phylogenetic criteria, we are of the opinion that strain $\mathrm{c} 14^{\mathrm{T}}$ isolated from surface water of a freshwater pond for shrimp culture should be assigned to a novel species of a new genus, for which the name Chitinilyticum aquatile gen. nov., sp. nov. is proposed.

\section{Description of Chitinilyticum gen. nov.}

Chitinilyticum (Chi.ti.ni.ly'ti.cum. N.L. n. chitinum chitin; N.L. adj. lyticus - a -um dissolving, used as subst. dissolver; N.L. neut. n. Chitinilyticum chitin-dissolver).

Cells are Gram-negative rods, motile by means of single polar flagella. PHB granules are stored as reserve material. Endospores are not formed. Colonies on $\mathrm{CB}$ medium display a large clear zone around them, which is derived from degradation of chitin. No diffusible pigments are produced. Grow well by using chitin as the sole carbon, nitrogen and energy source under both aerobic and anaerobic conditions. Positive for catalase and oxidase. Major fatty acid components are $\mathrm{C}_{16: 0}, \mathrm{C}_{18: 1} \omega 7 c$ and summed feature $3\left(\mathrm{C}_{16: 1} \omega 7 c\right.$ and/or $\mathrm{C}_{15: 0}$ iso 2-OH $)$. Major isoprenoid quinone is $\mathrm{Q} 8$. The $\mathrm{G}+\mathrm{C}$ content of the DNA of the type strain of the type species is $69.5 \mathrm{~mol} \%$. Based on 16S rRNA gene sequence analysis, Chitinilyticum belongs to the class Betaproteobacteria, family Neisseriaceae, showing a distant relatedness to Chitinibacter tainanensis, Silvimonas terrae, Deefgea rivuli and Formivibrio citricus. The type species is Chitinilyticum aquatile.

\section{Description of Chitinilyticum aquatile sp. nov.}

Chitinilyticum aquatile (L. neut. adj. aquatile living in water).

Displays the following properties in addition to those given in the genus description. Cells are 2.5-4.0 $\mu \mathrm{m}$ long and $0.3-0.4 \mu \mathrm{m}$ in diameter, occurring singly. Growth occurs at 15-40 ${ }^{\circ} \mathrm{C}, \mathrm{pH}-11$ and $0-0.75 \% \mathrm{NaCl}$. Positive for glucose fermentation. Negative for arginine dihydrolase, lysine decarboxylase, ornithine decarboxylase, citrate utilization, $\mathrm{H}_{2} \mathrm{~S}$ production (triple-sugar iron agar and sulfide indole motility medium), acetoin production (Voges-Proskauer test) and fermentation of mannitol, sucrose, arabinose and rhamnose. API 20NE tests show positive reactions for nitrate reduction, glucose fermentation, gelatin hydrolysis and assimilation of glucose, mannose, $N$-acetyl-D-glucosamine and gluconate and negative reactions for indole production, arginine dihydrolase, urease, aesculin hydrolysis, $\beta$-galactosidase and assimilation of arabinose, mannitol, maltose, caprate, adipate, malate, citrate and phenylacetate. In API ZYM tests, shows positive results for alkaline phosphatase, C4 esterase, C8 lipase, leucine arylamidase, acid phosphatase, naphthol-AS-BI-phosphohydrolase and $N$-acetyl- $\beta$-glucosaminidase and negative reactions for $\alpha$-glucosidase, 
$\beta$-glucuronidase, $\alpha$-galactosidase, $\beta$-galactosidase, $\beta$-glucosidase, C14 lipase, valine arylamidase, cystine arylamidase, $\alpha$-mannosidase, $\alpha$-fucosidase, trypsin and $\alpha$-chymotrypsin. The following carbon sources are oxidized (Biolog GN2): dextrin, glucose, D-fructose, sucrose, cellobiose, mannose, trehalose, turanose, gluconate, D-glucuronic acid, acetic acid, $\alpha$-ketobutyric acid, $\alpha$-ketovaleric acid, DL-lactate, $N$ acetyl-D-glucosamine, $\alpha$-hydroxybutyric acid, glucose 6phosphate and L-alanine. The following substrates are not utilized (Biolog GN2): $\alpha$-cyclodextrin, glycogen, Tween 40 , Tween 80, arabinose, maltose, lactulose, psicose, Dmelibiose, itaconic acid, L-fucose, inosine, $\alpha$-D-lactose, Dgalactose, D-raffinose, gentiobiose, L-rhamnose, mannitol, xylitol, glycerol, arabitol, $i$-erythritol, D-galacturonic acid, D-sorbitol, myo-inositol, adonitol, 2,3-butanediol, $\mathrm{N}$ acetyl-D-galactosamine, DL- $\alpha$-glycerol phosphate, glucose 1-phosphate, methyl $\beta$-D-glucoside, 2-aminoethanol, monomethyl succinate, citrate, formic acid, D-galactonic acid lactone, methyl pyruvate, malonic acid, $\alpha$-ketoglutaric acid, propionic acid, urocanic acid, D-saccharic acid, succinic acid, bromosuccinic acid, succinamic acid, phydroxyphenylacetic acid, cis-aconitic acid, quinic acid, sebacic acid, $\gamma$-aminobutyric acid, $\beta$-hydroxybutyric acid, $\gamma$-hydroxybutyric acid, D-glucosaminic acid, phenyl ethylamine, L-glutamic acid, L-histidine, L-aspartic acid, Lleucine, L-threonine, L-phenylalanine, L-asparagine, L-serine, D-alanine, D-serine, L-proline, hydroxy-L-proline, glycyl L-glutamic acid, L-ornithine, DL-carnitine, L-pyroglutamic acid, glycyl L-aspartic acid, L-alanyl glycine, putrescine, alaninamide, glucuronamide, thymidine and uridine. Sensitive to amikacin $(30 \mu \mathrm{g})$, ampicillin $(10 \mu \mathrm{g})$, chloramphenicol $(30 \mu \mathrm{g})$, kanamycin $(30 \mu \mathrm{g})$, nalidixic acid $(30 \mu \mathrm{g})$, novobiocin $(30 \mu \mathrm{g})$, rifampicin $(5 \mu \mathrm{g})$ and tetracycline $(30 \mu \mathrm{g})$. Resistant to erythromycin $(15 \mu \mathrm{g})$, gentamicin $(10 \mu \mathrm{g})$, penicillin $\mathrm{G}(10 \mathrm{U})$ and streptomycin $(10 \mu \mathrm{g})$.

The type strain, $\mathrm{c} 14^{\mathrm{T}}\left(=\mathrm{BCRC} 17533^{\mathrm{T}}=\mathrm{LMG} 23346^{\mathrm{T}}\right)$, was isolated from surface water of an aquaculture pond containing Pacific white shrimp (Litopenaeus vannamei) at Pingtung in southern Taiwan.

\section{Acknowledgements}

This research was supported by a grant from Tajen University, Taiwan, Republic of China (92090-3).

\section{References}

Chang, S. C., Wang, J. T., Vandamme, P., Hwang, J. H., Chang, P. S. \& Chen, W. M. (2004). Chitinimonas taiwanensis gen. nov., sp. nov., a novel chitinolytic bacterium isolated from a freshwater pond for shrimp culture. Syst Appl Microbiol 27, 43-49.

Chen, W. M., Laevens, S., Lee, T. M., Coenye, T., De Vos, P., Mergeay, M. \& Vandamme, P. (2001). Ralstonia taiwanensis sp. nov., isolated from root nodules of Mimosa species and sputum of a cystic fibrosis patient. Int J Syst Evol Microbiol 51, 1729-1735.

Chern, L. L., Stackebrandt, E., Lee, S. F., Lee, F. L., Chen, J. K. \& Fu, H. M. (2004). Chitinibacter tainanensis gen. nov., sp. nov., a chitin-degrading aerobe from soil in Taiwan. Int J Syst Evol Microbiol 54, 1387-1391.

Chun, J., Lee, J.-H., Jung, Y., Kim, M., Kim, S., Kim, B. K. \& Lim, Y. W. (2007). EzTaxon: a web-based tool for the identification of prokaryotes based on $16 \mathrm{~S}$ ribosomal RNA gene sequence. Int J Syst Evol Microbiol 57, 2259-2261.

Collins, M. D. (1985). Analysis of isoprenoid quinones. Methods Microbiol 18, 329-366.

Collins, M. D. (1994). Isoprenoid quinones. In Chemical Methods in Prokaryotic Systematics, pp. 265-309. Edited by M. Goodfellow \& A. G. O'Donnell. Chichester: Wiley.

Ezaki, T., Hashimoto, Y. \& Yabuuchi, E. (1989). Fluorometric deoxyribonucleic acid-deoxyribonucleic acid hybridization in microdilution wells as an alternative to membrane filter hybridization in which radioisotopes are used to determine genetic relatedness among bacterial strains. Int J Syst Bacteriol 39, 224-229.

Felsenstein, J. (1981). Evolutionary trees from DNA sequences: a maximum likelihood approach. J Mol Evol 17, 368-376.

Genetics Computer Group (1995). Wisconsin Package Version 8.1 Program Manual. Madison, WI: Genetics Computer Group.

Gooday, G. W. (1990). The ecology of chitin degradation. Adv Microb Ecol 11, 387-430.

Hall, T. A. (1999). BioEdit: a user-friendly biological sequence alignment editor and analysis program for Windows 95/98/NT. Nucleic Acids Symp Ser 41, 95-98.

Hippe, H., Hagelstein, A., Kramer, I., Swiderski, J. \& Stackebrandt, E. (1999). Phylogenetic analysis of Formivibrio citricus, Propionivibrio dicarboxylicus, Anaerobiospirillum thomasii, Succinimonas amylolytica and Succinivibrio dextrinosolvens and proposal of Succinivibrionaceae fam. nov. Int J Syst Bacteriol 49, 779-782.

Jukes, T. H. \& Cantor, C. R. (1969). Evolution of protein molecules. In Mammalian Protein Metabolism, vol. 3, pp. 21-132. Edited by H. N. Munro. New York: Academic Press.

Kluge, A. G. \& Farris, F. S. (1969). Quantitative phyletics and the evolution of anurans. Syst Zool 18, 1-32.

Kumar, S., Tamura, K. \& Nei, M. (2004). MEGA3: integrated software for molecular evolutionary genetics analysis and sequence alignment. Brief Bioinform 5, 150-163.

Logan, N. A. (1989). Numerical taxonomy of violet-pigmented, gramnegative bacteria and description of Iodobacter fluviatile gen. nov., comb. nov. Int J Syst Bacteriol 39, 450-456.

Ludwig, W., Strunk, O., Klugbauer, S., Klugbauer, N., Weizenegger, M., Neumaier, J., Bachleitner, M. \& Schleifer, K. H. (1998). Bacterial phylogeny based on comparative sequence analysis. Electrophoresis 19, 554-568.

MacFaddin, J. F. (2000). Biochemical Tests for the Identification of Medical Bacteria, 3rd edn. Baltimore, MD: Williams \& Wilkins.

Mesbah, M., Premachandran, U. \& Whitman, W. B. (1989). Precise measurement of the $\mathrm{G}+\mathrm{C}$ content of deoxyribonucleic acid by highperformance liquid chromatography. Int J Syst Bacteriol 39, 159-167.

MIDI Inc. (1999). Sherlock Microbial Identification System, Operating Manual, version 3.0. Newark, DE: MIDI, Inc.

Powers, E. M. (1995). Efficacy of the Ryu nonstaining $\mathrm{KOH}$ technique for rapidly determining gram reactions of food-borne and waterborne bacteria and yeasts. Appl Environ Microbiol 61, 3756-3758.

Saitou, N. \& Nei, M. (1987). The neighbor-joining method: a new method for reconstructing phylogenetic trees. Mol Biol Evol 4, 406-425.

Sasser, M. (1990). Identification of bacteria by gas chromatography of cellular fatty acids, MIDI Technical Note 101. Newark, DE: MIDI Inc. 
Shigemasa, Y. \& Minami, S. (1996). Applications of chitin and chitosan for biomaterials. Biotechnol Genet Eng Rev 13, 383-420.

Stackebrandt, E., Lang, E., Cousin, S., Päuker, O., Brambilla, E., Kroppenstedt, R. \& Lünsdorf, H. (2007). Deefgea rivuli gen. nov., sp. nov., a member of the class Betaproteobacteria. Int J Syst Evol Microbiol 57, 639-645.

Tanaka, K., Nakamura, K. \& Mikami, E. (1991). Fermentation of Scitramalate, citrate, mesaconate, and pyruvate by a gram-negative strictly anaerobic non-spore-former, Formivibrio citricus gen. nov., sp. nov. Arch Microbiol 155, 491-495.
Wayne, L. G., Brenner, D. J., Colwell, R. R., Grimont, P. A. D., Kandler, O., Krichevsky, M. I., Moore, L. H., Moore, W. E. C., Murray, R. G. E. \& other authors (1987). International Committee on Systematic Bacteriology. Report of the ad hoc committee on reconciliation of approaches to bacterial systematics. Int J Syst Bacteriol 37, 463-464.

Yang, H.-C., Im, W.-T., An, D.-S., Park, W.-S., Kim, I. S. \& Lee, S.-T. (2005). Silvimonas terrae gen. nov., sp. nov., a novel chitin-degrading facultative anaerobe belonging to the 'Betaproteobacteria'. Int J Syst Evol Microbiol 55, 2329-2332. 